\title{
Dietary and other lifestyle correlates of serum folate concentrations in a healthy adult population in Crete, Greece: a cross-sectional study
}

\author{
Christos M Hatzis ${ }^{1}$, George K Bertsias ${ }^{1}$, Manolis Linardakis ${ }^{1}$, John M Scott ${ }^{2}$ \\ and Anthony G Kafatos*1
}

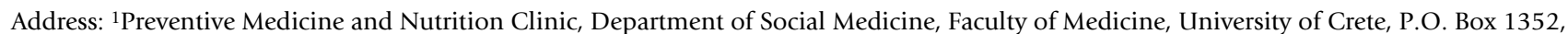
71110, Heraklion, Greece and 2Biochemistry Department, Trinity College Dublin, Dublin 2, Ireland

Email: Christos M Hatzis - kafatos@med.uoc.gr; George K Bertsias - gbert@med.uoc.gr; Manolis Linardakis - linman@med.uoc.gr; John M Scott - jscott@tcd.ie; Anthony G Kafatos* - kafatos@med.uoc.gr

* Corresponding author

Published: 10 February 2006

Nutrition Journal2006, 5:5 doi:10.1/86//475-289/-5-5

This article is available from: http://www.nutritionj.com/content/5/I/5

(c) 2006Hatzis et al; licensee BioMed Central Ltd.

This is an Open Access article distributed under the terms of the Creative Commons Attribution License (http://creativecommons.org/licenses/by/2.0), which permits unrestricted use, distribution, and reproduction in any medium, provided the original work is properly cited.
Received: 14 October 2005

Accepted: 10 February 2006

\begin{abstract}
Background: Folate has emerged as a key nutrient for optimising health. Impaired folate status has been identified as a risk factor for cardiovascular disease, various types of cancers, and neurocognitive disorders. The study aimed at examining the distribution and determinants of serum folate concentrations in a healthy adult population in Crete, Greece.

Methods: A cross-sectional sample of 486 healthy adults ( 250 men, 236 women) aged $39 \pm 14$ years, personnel of the Medical School and the University Hospital of Crete in Greece, was examined. Serum folate and vitamin $B_{12}$ concentrations were measured by microbiological assay, and total homocysteine was determined fluorometrically and by high-pressure liquid chromatography. Lifestyle questionnaires were completed, and nutrient intakes and food consumption were assessed by $24-\mathrm{h}$ dietary recalls. Multivariate analyses were performed using SPSS v10.I.

Results: The geometric mean ( $95 \%$ confidence interval) concentrations of serum folate were $15.6 \mu \mathrm{mol} /$ I ( $14.6-16.8)$ in men and $19.2 \mu \mathrm{mol} / /(17.9-20.7)$ in women $(\mathrm{p}<0.00 \mathrm{I})$. Inadequate folate levels $(\leq 7 \mathrm{nmol} /$ l) were present in $6.8 \%$ of men and $2.1 \%$ of women $(\mathrm{p}<0.00 \mathrm{I})$. Approximately $76 \%$ of men and $87 \%$ of women did not meet the reference dietary intake for folate $(400 \mu \mathrm{g} /$ day $)$. Serum folate was inversely related to total homocysteine levels $(p<0.001)$. Increased tobacco and coffee consumption were associated with lower folate concentrations ( $P<0.05$ for both) but these associations disappeared after controlling for nutrient intakes. In multivariate analysis, intakes of MUFA, fibre, calcium, magnesium, folate, and vitamins $A, E, C, B_{1}$, and $B_{6}$ were positively associated with serum folate. Consumption of potatoes, legumes, fruits, and vegetables were favourably related to the serum folate status.

Conclusion: Serum folate concentrations were associated with various demographic, lifestyle and dietary factors in healthy Cretan adults. Large-scale epidemiological studies should be conducted within the general Greek adult population to assess the prevalence of impaired folate status and further examine associations with dietary patterns and chronic disease risk. Considering the importance of folate in health maintenance, it is important to increase the public's awareness of modifiable lifestyle patterns and diet and tobacco use in particular, which may be associated with improved folate status.
\end{abstract}




\section{Background}

Dietary habits in a population may be a determining factor of health, and inadequate intakes of certain nutrients have been associated with increased risk for chronic disease, such as cardiovascular disease, diabetes, and cancer. More recently, folate has drawn attention as a key nutrient involved in health maintenance and chronic disease prevention [1]. Folate acts as a coenzyme in several single-carbon transfers leading to the biosynthesis of nucleic acids, certain neurotrasmitters, phospholipids, and hormones. It is involved in homocysteine metabolism, donating a methyl group during homocysteine remethylation into methionine, and inadequate folate status has been characterized as a major cause of hyperhomocysteinaemia [2]. Moreover, folate deficiency is an established risk factor for the development of certain types of cancer, cardiovascular disease [3,4], developmental defects (e.g. neural tube defects), and neurological or psychiatric disorders [5-7]. Although much of the adverse effects of impaired folate status is explained through its interplay with homocysteine levels, there is evidence suggesting direct healthbeneficial effects of folate, including its favourable effects on vascular endothelial function and redox cellular status [1].

From a public health perspective, assessing the folate status in a population and examining its dietary or other correlates, is of great importance. This would allow the identification of groups at risk for folate deficiency that would mostly benefit from public health interventions to increase dietary folate intake.

Crete (Greece), once known for the low cardiovascular mortality among adult men in early 1950's, has now increasing rates of cardiovascular disease, a trend that appears to be related to dietary and lifestyle changes that have been taking place during the last decades [8,9]. The traditional Cretan diet - a variant of the Mediterranean diet - has been gradually abandoned, and current Cretans consume higher amounts of saturated fat, meat, and cheese, and lower amounts of bread, fruits, vegetables, legumes, and fibre [9-11]. Among other consequences, such dietary changes are expected to result in decreased intake of dietary folate and thus, impaired folate status. To date, however, no data are available with regard to the folate status of the adult population in Crete.

In this study, we report on the folate status of a group of apparently healthy Cretan adults, personnel of the University of Crete and the University Hospital of Heraklion (Crete), which were examined as part of a health prevention programme by the Preventive Medicine and Nutrition Clinic. We describe the distribution of serum folate concentrations by age and sex, and investigate associations with nutrient intakes, food consumption, and life- style habits, namely tobacco, coffee, and alcohol consumption. Our findings document certain patterns of dietary intake and lifestyle habits associated with folate levels, with potential implications for the development of future health intervention studies.

\section{Methods \\ Study sample}

The study was conducted as part of a health prevention programme undertaken by the Preventive Medicine and Nutrition Clinic at the University of Crete School of Medicine. The personnel of University Hospital of Heraklion (Crete, Greece) and the University of Crete School of Medicine were asked to participate in the health assessment survey by written announcements. Subjects were excluded if they had history of any chronic disease such as cancer, diabetes mellitus, hypertension, liver or coronary heart disease. The study sample consisted of 381 (out of 2445) employees (184 men, 197 women, aged $20-72$ years) and 105 (out of 155) (66 men, 39 women, aged 20-40 years) practicing medical students.

\section{Laboratory measurements}

Early morning venous blood samples were drawn for biochemical screening tests, following a 12-hour overnight fast. The blood samples $(10 \mathrm{ml})$ were transferred to the Nutritional Research Laboratory of the University of Crete in tanks containing ice packs so as to maintain a temperature of $3-4^{\circ} \mathrm{C}$. Blood was centrifuged and $1.5 \mathrm{ml}$ aliquots were pipetted into plastic Eppendorf tubes. One aliquot was used for blood analysis of triacylglycerol (TG), total cholesterol (TC) and high-density lipoprotein cholesterol (HDL-C) measurements [12] on the same day of collection, while the other was stored (at $-80^{\circ} \mathrm{C}$ ) for determination of serum folate, vitamin $\mathrm{B}_{12}$, and total homocysteine. Serum samples were sent in dry ice to Trinity College of Dublin (Ireland), and serum folate and vitamin $B_{12}$ concentrations were measured by a 96-well plate microbiological assay $[13,14]$. Serum total homocysteine concentrations were determined fluorometrically and by high-pressure liquid chromatography (HPLC) [15].

\section{Health assessment questionnaires}

Purpose designed questionnaires were administered to ascertain biographical data, lifestyle behaviours on topics including cigarette smoking and medical history [12]. To validate the results, multiple crosschecked questions on the same topic were addressed to the participants. Smokers were classified as those who stated smoking more than one cigarette per day for at least three consecutive months. Ex-smokers were defined as those who had not been smoking for the last six consecutive months, and nonsmokers as those who did not fall in any of the two previous groups. 
Table I: Demographics and other characteristics of the study sample of Cretan adults.

\begin{tabular}{|c|c|c|c|}
\hline & Men $(N=250)$ & Women $(\mathrm{N}=236)$ & \multirow{3}{*}{$\frac{p \text { value }^{1}}{-2}$} \\
\hline & \multicolumn{2}{|c|}{ Mean (SD) or \% } & \\
\hline Age (years) & $39(14)$ & $39(13)$ & \\
\hline District of residence (\% urban) & 86.4 & 85.6 & - \\
\hline Tobacco use (\% current use) & 37.7 & 31.0 & - \\
\hline $\mathrm{BMI}\left(\mathrm{kg} / \mathrm{m}^{2}\right)$ & $26.8(3.5)$ & $26.1(5.8)$ & $<0.001$ \\
\hline Systolic blood pressure $(\mathrm{mmHg})$ & $129.4(16.7)$ & $124.2(20.3)$ & $<0.001$ \\
\hline Diastolic blood pressure $(\mathrm{mmHg})$ & $84.3(10.0)$ & $79.2(10.9)$ & $<0.001$ \\
\hline Total cholesterol (mg/dL) & $224.0(50.3)$ & $221.7(54.0)$ & - \\
\hline Triglycerides (mg/dL) & $128.2(83.3)$ & $99.9(56.9)$ & $<0.001$ \\
\hline HDL-cholesterol (mg/dL) & $45.3(9.8)$ & $56.5(12.2)$ & $<0.001$ \\
\hline Energy intake (kcal/day) ${ }^{3}$ & $2133(793)$ & 1605 (629) & $<0.001$ \\
\hline Total fat (\% energy) ${ }^{3}$ & $39.7(9.8)$ & 40.2 (II.I) & - \\
\hline SFA (\% energy) ${ }^{3}$ & II.5 (5.0) & $11.1(4.9)$ & - \\
\hline Dietary cholesterol (mg/day) ${ }^{3}$ & $213.7(157.4)$ & $153.6(130.9)$ & $<0.001$ \\
\hline Dietary fibre $(g / \text { day })^{3}$ & $22.1(11.3)$ & $18.7(11.0)$ & 0.001 \\
\hline
\end{tabular}

I Analysis of variance (ANOVA) or chi-squared test.

2 Not statistically significant.

${ }^{3} \mathrm{~N}=197$ for men and $\mathrm{N}=186$ for women

\section{Dietary survey}

Dieticians administered a $24 \mathrm{~h}$ dietary recall to all participants. Detailed descriptions of all foods, beverages and supplements consumed during the $24 \mathrm{~h}$ period before the interview, including the quantity, cooking method and brand names were recorded. Dietary records were collected from 383 participants (197 men, 186 women). Food quantities were assessed by the use of household measures and colour food-model photographs. The $24 \mathrm{~h}$ dietary recall has been previously validated in relation to fat intake based on measurements with adipose tissue aspiration and fatty acid composition analysis [8]. Nutrient contents were analysed according to the food database developed at the Department of Social Medicine of the University of Crete in 1998 and updated in 2000 [11]. The database includes about 500 foods, both single and composite. The macro- and micro-nutrient composition of about 20 foods has been chemically determined at Wageningen Agricultural University. The fatty acid content of 105 fat-containing foods was determined at the TNO Nutrition and Food Research Institute (The Netherlands) during 1997. For the remainder of fat-containing foods, the fatty acid analyses were drawn from the analyses available within the European "trans fatty acid research project" database (TTDB, version 1.2) developed at the TNO Nutrition and Food Research Institute between 1995 and 1997. For the foods whose composition was not chemically determined, values from the US Department of Agriculture database v11.1 were used. Recipe calculations were used for composite Greek foods with the ingredients being weighed prior to and also following cooking in each case.

\section{Statistical analyses}

The distribution of serum folate was markedly skewed toward high values and was corrected by log transformation. The geometric means and their 95\% confidence intervals (CI) are presented. Variables not normally distributed were also log-transformed. We tested for statistically significant differences between men and women using one-way analysis of variance (ANOVA). The chisquared $\left(\chi^{2}\right)$ test was used for categorical variables. Serum folate concentrations were considered sub-optimal when $\leq 7 \mathrm{nmol} / \mathrm{l}$ [16]. To estimate mean total homocysteine and vitamin $\mathrm{B}_{12}$ concentrations across levels of serum folate, age and sex-specific quartiles were calculated. Geometric mean (95\% CI) folate concentrations within categories of tobacco, coffee, and alcohol consumption were determined by analysis of covariance (ANCOVA), controlling for age, gender, district of residence (rural/urban), energy intake, and intakes of several nutrients which were significantly associated to serum folate (MUFA, fibre, calcium, magnesium, folate, vitamins $\left.A, E, C, B_{1}, B_{6}\right)$. Linear contrasts were applied to test for trends across groups with $\geq 3$ groups and collinearity was assessed by calculation of variance inflation factors (VIF).

Nutrient intakes were calculated across age and sex-specific quartiles of serum folate, and Pearson's partial correlation coefficients $(r)$ were used to evaluate linear associations between nutrient intakes and serum folate after controlling for age, gender, district of residence, body mass index, energy intake, and consumption of tobacco, coffee, and alcohol. Finally, individuals were categorized according to levels of consumption of various foods 
Table 2: Serum folate concentrations and dietary intake of folate in the study sample of Cretan adults.'

\begin{tabular}{|c|c|c|c|c|c|c|c|}
\hline & & Serum folate & $\% \leq 7$ & & Folate intake & & $\%<400$ \\
\hline & & $(\mathrm{nmol} / \mathrm{l})^{2}$ & $\mathrm{nmol} / \mathrm{l}$ & & $(\mu \mathrm{g} / \mathrm{d})^{3}$ & $(\mu \mathrm{g} / 1000 \mathrm{kcal} / \mathrm{d})$ & $\mu g / d$ \\
\hline \multicolumn{8}{|l|}{ Men } \\
\hline $20-34$ y & $(n=107)$ & $13.8(\mid 2.5-15.3)$ & 7.5 & $(n=103)$ & $248(2 \mid 3-283)$ & $119(106-133)$ & 83.5 \\
\hline $35-50 y$ & $(n=80)$ & $16.0(14.2-18.0)$ & 6.3 & $(n=72)$ & 351 (297-406) & $174(149-198)$ & 69.4 \\
\hline$>50 y$ & $(n=63)$ & $18.6(15.8-21.9)^{4}$ & 6.3 & $(n=20)$ & $325(242-407)^{5}$ & $166(130-201)^{6}$ & 65.0 \\
\hline Total & $(n=250)$ & $15.6(14.6-16.8)$ & 6.8 & $(n=195)$ & $294(265-323)$ & $144(132-157)$ & 76.4 \\
\hline \multicolumn{8}{|l|}{ Women } \\
\hline $20-34$ y & $(n=101)$ & $17.4(15.8-19.2)$ & 3.0 & $(n=96)$ & 247 (207-288) & $159(134-184)$ & 86.5 \\
\hline $35-50 y$ & $(n=79)$ & $19.4(17.2-22.0)$ & 1.3 & $(n=72)$ & 242 (198-287) & 155 (133-177) & 88.9 \\
\hline$>50 y$ & $(n=56)$ & $22.8(19.3-26.9)^{7}$ & 1.8 & $(\mathrm{n}=17)$ & $266(160-372)$ & $192(129-255)$ & 76.5 \\
\hline Total & $(n=236)$ & $19.2(17.9-20.7)$ & 2.1 & $(n=185)$ & 247 (219-275) & 161 (144-177) & 86.5 \\
\hline
\end{tabular}

I Data are presented as geometric mean ( $95 \%$ confidence interval).

2 Men had significantly lower serum folate concentrations than women $(p<0.001)$.

3 Men had significantly higher intake of dietary folate $(\mu g / d)$ than women $(p=0.003)$.

${ }^{4} p=0.001$ (trend by age).

${ }^{5} p=0.003$ (trend by age).

${ }^{6} p<0.001$ (trend by age).

${ }^{7} p=0.008$ (trend by age).

(none, below or above median consumption) and levels of serum folate (below or above $1^{\text {st }}$ quartile, age- and gender-specific). Logistic regression was used to calculate odds ratio $(95 \% \mathrm{CI})$ for low serum folate $\left(<1^{\text {st }}\right.$ quartile $)$ according to consumption of foods, including district of residence, body mass index, energy intake, and consumption of tobacco, coffee, and alcohol as independent variables. All the $p$ values reported are two-tailed and statistical significance was defined as $p<0.05$. Statistical analyses were performed using the Statistical Package for Social Sciences (SPSS for Windows 11.5.0, SPSS, Inc.).

\section{Results}

The mean \pm standard deviation $(S D)$ age was $39 \pm 14$ years for men and $39 \pm 13$ years for women (Table 1 ). Approximately $86 \%$ of the subjects lived in urban areas and current smokers were the $38 \%$ of men and $31 \%$ of women ( $p$ $>0.05$ ).
The distribution of serum folate concentrations and dietary folate intakes is presented for all subjects by gender and age in Table 2. The geometric mean of serum folate was $15.6 \mathrm{nmol} / \mathrm{l}(95 \% \mathrm{CI}, 14.6-16.8 \mathrm{nmol} / \mathrm{l})$ in men and $19.2 \mathrm{nmol}(17.9-20.7 \mathrm{nmol} / \mathrm{l})$ in women $(p<0.001)$. In both men and women age was positively associated with serum folate. The prevalence of sub-optimal serum folate $(\leq 7 \mathrm{nmol} / \mathrm{l})$ was $6.8 \%$ in men and $2.1 \%$ in women $(p<$ $0.001)$. Men had higher mean intake of dietary folate than women $(294$ vs. $247 \mu \mathrm{g} / \mathrm{d}, p=0.003)$. However, the energy-adjusted intake of folate was higher in women than men ( 161 vs. $144 \mu \mathrm{g} / 1000 \mathrm{kcal} / \mathrm{d}, p>0.05)$. Eightyseven percent of women and $76 \%$ of men $(p=0.013)$ consumed folate $<400 \mu \mathrm{g} /$ day. Dietary intake of folate increased by age, especially in men ( $p$ for trend $<0.01$ ).

Associations between age and sex-specific quartiles of serum folate and mean levels of total homocysteine and

Table 3: Association between serum total homocysteine and vitamin $B_{12}$ concentrations and quartiles (age and sex-specific) of serum folate in Cretan adults.

\begin{tabular}{|c|c|c|c|c|c|}
\hline & \multicolumn{4}{|c|}{ Serum folate quartiles (age \& gender-specific) } & \\
\hline & QI & Q2 & Q3 & Q4 & \\
\hline & \multicolumn{4}{|c|}{ Geometric mean } & $p$ for trend \\
\hline Serum total homocysteine $(\mu \mathrm{mol} / \mathrm{L})$ & 12.4 & 10.3 & 10.2 & 10.1 & $<0.001$ \\
\hline Serum vitamin $B_{12}(\mathrm{pmol} / \mathrm{L})$ & 307.5 & 305.2 & 310.4 & 286.1 & -2 \\
\hline
\end{tabular}

I ANOVA (linear contrasts).

2 Not statistically significant. 
Table 4: Association between serum folate concentrations and consumption of tobacco, coffee, and alcohol in the study sample of Cretan adults.

\begin{tabular}{|c|c|c|}
\hline & Age- \& gender-adjusted I & Multivariate-adjusted 2 \\
\hline & \multicolumn{2}{|c|}{ Geometric mean $(95 \% \mathrm{Cl})$} \\
\hline \multicolumn{3}{|l|}{ Tobacco consumption } \\
\hline Non/ex-smokers $(n=3 \mid 4)$ & $18.0(16.9-19.1)$ & $17.4(16.3-18.6)$ \\
\hline Current smokers $(n=165)$ & $16.0(14.7-17.4)^{3}$ & $16.2(14.9-17.7)$ \\
\hline$<10$ cigs $/$ day $(n=52)$ & $17.7(\mid 5.3-20.5)$ & $16.5(14.1-19.4)$ \\
\hline $10-19$ cigs/day $(n=36)$ & $15.0(12.6-17.9)$ & $14.7(12.2-17.8)$ \\
\hline$\geq 20 \mathrm{cigs} /$ day $(\mathrm{n}=76)$ & $14.6(12.9-16.5)^{4}$ & $14.9(12.9-17.2)$ \\
\hline \multicolumn{3}{|l|}{ Coffee consumption } \\
\hline None $(n=102)$ & $18.2(16.4-20.2)$ & $17.9(16.2-19.8)$ \\
\hline$\leq 200$ g/day $(n=195)$ & $16.9(15.7-18.2)$ & $17.2(16.0-18.5)$ \\
\hline$>200$ g/day $(n=86)$ & $15.5(13.8-17.3)^{5}$ & $15.6(14.0-17.4)$ \\
\hline \multicolumn{3}{|l|}{ Alcohol consumption } \\
\hline None $(n=293)$ & $17.0(16.0-18.1)$ & $17.0(16.0-18.0)$ \\
\hline$\leq 180 \mathrm{~g} /$ day $(\mathrm{n}=43)$ & $16.0(13.6-18.9)$ & $16.1(13.8-18.9)$ \\
\hline$>180 \mathrm{~g} /$ day $(\mathrm{n}=47)$ & $16.8(14.4-19.7)$ & $18.2(\mid 5.6-21.2)$ \\
\hline
\end{tabular}

I ANCOVA, controlling for age and gender.

${ }^{2}$ ANCOVA, controlling for age, gender, district of residence, total energy intake, intakes of MUFA, fibre, calcium, magnesium, folate, vitamins A, E, $C, B_{1}, B_{6}$ (all log transformed).

${ }^{4}$ Non/ex-smokers had significantly higher serum folate concentrations than current smokers $(p=0.029)$.

${ }^{5} p=0.047$, linear trend by level of tobacco consumption.

${ }^{6} p=0.035$, linear trend by level of coffee consumption.

vitamin $B_{12}$ are presented in Table 3. Serum folate showed an inverse linear association with total homocysteine $(p$ for trend $<0.001$ ), and subjects at the highest folate quartile had $18.5 \%$ lower mean total homocysteine concentrations compared to those at the lowest quartile. No significant association was observed between serum folate and vitamin $B_{12}$ levels.

The relations between serum folate and the use of tobacco, coffee, and alcohol are shown in Table 4. The age- and gender-adjusted geometric mean serum folate was $\approx 2 \mathrm{nmol} / 1$ lower in current smokers than in non- or ex-smokers $(p<0.05)$. Similarly, serum folate levels were inversely related to the quantity of tobacco ( $p$ for trend $<$ 0.05 ), and individuals who smoked $\geq 20$ cigs/day had $21.2 \%$ lower mean folate concentrations compared to those who smoked $<10 \mathrm{cigs} /$ day. Increasing coffee intake was also related to decreased serum folate ( $p$ for trend $<$ $0.05)$, and subjects consuming $>200 \mathrm{~g} /$ day had $14.8 \%$ lower mean serum folate levels compared to non-consumers. However, the associations between tobacco or coffee consumption and serum folate disappeared after adjusting for intakes of nutrients, especially dietary folate, vitamins A and C (multivariate-adjusted). No significant relationship was observed between alcohol intake and serum folate.
The associations between nutrient intakes and serum folate are shown in Table 5. In multivariate analysis, intake of mono-unsaturated fatty acids (MUFA) - both as raw quantity and as percentage of energy intake - was positively associated with serum folate. Intakes of dietary fibre $(r=0.20)$, calcium $(r=0.14)$, and magnesium $(r=$ $0.10)$ were also positively related to serum folate, independently of age, gender, energy intake, consumption of tobacco, coffee, and alcohol. Serum folate concentrations demonstrated favourable associations with dietary intakes of several vitamins, namely folate $(r=0.14)$, vitamins A $(r$ $=0.23), \mathrm{E}(r=0.15), \mathrm{C}(r=0.21), \mathrm{B}_{1}(r=0.13)$, and $\mathrm{B}_{6}(r$ $=0.12)$.

We further assessed food consumption by the study participants according to their serum folate status (Table 6). Multivariate logistic regression analysis showed that increased consumption of potatoes, legumes, fruits and/ or vegetables were associated with decreased risk for low serum folate (determined as folate concentrations $<1^{\text {st }}$ quartile, age- and gender-specific). Specifically, individuals consuming fruits and/or vegetables $\geq 360 \mathrm{~g} /$ day had $79 \%$ lower risk for low serum folate, compared to those with no consumption. In contrast, increased intake of cereals and meat (especially red meat) was inversely related to serum folate status. 
Table 5: Mean nutrient intakes in relation to serum folate quartiles in the study sample of Cretan adults.

\begin{tabular}{|c|c|c|c|c|c|c|}
\hline & \multicolumn{4}{|c|}{ Serum folate quartiles (age- $\&$ gender-specific) } & \multicolumn{2}{|c|}{ Correlation coefficient $(r)$} \\
\hline & QI & Q2 & Q3 & Q4 & $\begin{array}{l}\text { Age/gender- } \\
\text { adjusted }\end{array}$ & $\begin{array}{l}\text { Multivariate- } \\
\text { adjusted }^{2}\end{array}$ \\
\hline Energy (kcal) & 1700 & 1769 & 1595 & 1647 & -0.03 & - \\
\hline Carbohydrates (g) & 179.1 & 184.7 & 192.7 & 185.2 & -0.01 & 0.03 \\
\hline$\%$ energy & 44.5 & 45.3 & 47.7 & 45.4 & 0.03 & 0.03 \\
\hline Protein $(\mathrm{g})$ & 67.8 & 60.0 & 62.4 & 61.3 & -0.06 & -0.06 \\
\hline$\%$ energy & 14.5 & 13.3 & 13.2 & 14.0 & -0.06 & -0.06 \\
\hline Total fat $(g)$ & 72.6 & 72.5 & 70.8 & 72.3 & -0.01 & 0.02 \\
\hline$\%$ energy & 41.1 & 40.9 & 39.5 & 40.2 & 0.00 & 0.00 \\
\hline SFA $(g)$ & 19.3 & 19.6 & 19.4 & 18.3 & -0.05 & -0.05 \\
\hline$\%$ energy & 11.7 & 11.6 & 11.7 & 11.0 & -0.04 & -0.05 \\
\hline PUFA (g) & 8.8 & 9.2 & 8.8 & 8.7 & 0.00 & 0.03 \\
\hline$\%$ energy & 5.4 & 5.5 & 5.3 & 5.2 & 0.01 & 0.01 \\
\hline MUFA (g) & 30.1 & 33.0 & 31.6 & 33.7 & 0.09 & $0.12^{3}$ \\
\hline$\%$ energy & 18.4 & 19.6 & 18.9 & 20.6 & $0.13^{3}$ & $0.12^{3}$ \\
\hline Trans FA (g) & 1.4 & 1.3 & 1.5 & 1.1 & -0.08 & -0.07 \\
\hline $\mathrm{n}-6$ FA (g) & 8.8 & 8.0 & 8.3 & 7.4 & -0.05 & -0.02 \\
\hline $\mathrm{n}-3$ FA (g) & 0.9 & 0.7 & 0.8 & 0.6 & -0.05 & -0.03 \\
\hline Cholesterol (mg) & 192.4 & 170.2 & 206.1 & 166.3 & -0.04 & -0.03 \\
\hline Fibre $(g)$ & 13.5 & 16.3 & 18.1 & 18.0 & $0.17^{4}$ & $0.20^{5}$ \\
\hline Calcium (mg) & 549.5 & 622.9 & 648.3 & 697.1 & $0.10^{3}$ & $0.14^{3}$ \\
\hline Iron (mg) & 10.6 & 10.5 & 11.6 & 11.2 & 0.04 & 0.08 \\
\hline Magnesium (mg) & 233.7 & 243.5 & 238.8 & 258.7 & 0.04 & $0.10^{3}$ \\
\hline Phosphorous (mg) & 928.6 & 946.2 & 917.2 & 946.0 & -0.03 & -0.02 \\
\hline Sodium (mg) & 1507 & 1583 & 1678 & 1492 & -0.02 & 0.01 \\
\hline Potassium (mg) & 2289 & 2191 & 2185 & 2565 & 0.08 & 0.09 \\
\hline Folate $(\mu \mathrm{g})$ & 187.8 & 211.1 & 220.9 & 232.5 & $0.11^{3}$ & $0.14^{4}$ \\
\hline Niacin (mg) & 13.3 & 13.1 & 14.0 & 12.7 & -0.03 & 0.01 \\
\hline Vitamin A ( $\mu \mathrm{g})$ & 538.1 & 546.6 & 768.3 & 1011 & $0.23^{5}$ & $0.23^{5}$ \\
\hline Vitamin E (mg) & 6.1 & 7.0 & 7.0 & 7.6 & $0.15^{4}$ & $0.15^{4}$ \\
\hline Vitamin C (mg) & 75.5 & 80.9 & 93.4 & 133.4 & $0.22^{5}$ & $0.21^{5}$ \\
\hline Vitamin $B_{1}(\mathrm{mg})$ & 1.2 & 1.3 & 1.4 & 1.4 & 0.09 & $0.13^{3}$ \\
\hline Vitamin $B_{2}(\mathrm{mg})$ & 1.2 & 1.3 & 1.4 & 1.4 & 0.04 & 0.06 \\
\hline Vitamin $B_{6}(\mathrm{mg})$ & 1.3 & 1.3 & 1.3 & 1.5 & 0.09 & $0.12^{3}$ \\
\hline Vitamin $B_{12}(\mu g)$ & 4.0 & 3.1 & 4.0 & 3.0 & -0.03 & -0.03 \\
\hline
\end{tabular}

I Partial correlation coefficient between intakes of nutrients and serum folate concentrations (all log transformed) controlling for age and gender. 2 Partial correlation coefficient between intakes of nutrients and serum folate concentrations (all log transformed) controlling for age, gender, district of residence, body mass index, energy intake, consumption of tobacco, coffee, and alcohol.

${ }^{3} p<0.05$

${ }^{4} p<0.01$

${ }^{5} p<0.001$

\section{Discussion}

Folate has recently emerged as a key nutrient to optimising health, and inadequate folate status has been identified as risk factor for cardiovascular disease, various types of cancers, and neurocognitive disorders [1,17]. The present study described the distribution of serum folate concentrations in a healthy adult population in Crete, Greece and examined associations with dietary intakes and lifestyle habits, namely tobacco, coffee, and alcohol consumption. The relationship between serum folate and vitamin $\mathrm{B}_{12}$ and total homocysteine was also examined.
The results of the study should be viewed in light of some limitations. The present data used a cross-sectional design that implies that no conclusions can be drawn on the causal effect of the determinants of serum folate levels. The dietary survey was performed using one single 24-h dietary record and may thus be subject to both systematic and random bias, one source being the lack of inclusion of weekends. The regular use of vitamin supplements was not recorded and this precluded further analyses of the serum folate status. Also, the participation rate was relatively low $(<20 \%)$ and selection bias cannot be excluded. Lastly, the unique sample of Hospital/Medical School personnel is both strength (as it decreases potential for con- 
Table 6: Association between foods consumption and serum folate status in the study sample of Cretan adults.

\begin{tabular}{|c|c|c|}
\hline & \multicolumn{2}{|c|}{ Odds ratio $(95 \% \mathrm{Cl})$ for low serum folate $\left(<\left.\right|^{\text {st }}\right.$ quartile, age- $\&$ gender-specific } \\
\hline & Unadjusted' & Multivariate-adjusted ${ }^{2}$ \\
\hline \multicolumn{3}{|l|}{ Bread } \\
\hline None & 1.00 (reference) & 1.00 (reference) \\
\hline$<90 \mathrm{~g}$ & $0.81(0.38-1.73)$ & $0.76(0.35-1.64)$ \\
\hline \multirow{2}{*}{$\geq 90 \mathrm{~g}$} & $0.74(0.35-1.58)$ & $0.71(0.33-1.52)$ \\
\hline & $p=0.451$ & $p=0.428$ \\
\hline \multicolumn{3}{|l|}{ Cereals } \\
\hline None & 1.00 (reference) & 1.00 (reference) \\
\hline$<90 \mathrm{~g}$ & $1.47(0.82-2.63)$ & $1.46(0.79-2.68)$ \\
\hline \multirow[t]{2}{*}{$\geq 90 \mathrm{~g}$} & $1.74(1.01-3.02)$ & $1.75(0.98-3.12)$ \\
\hline & $p=0.045$ & $p=0.057$ \\
\hline \multicolumn{3}{|l|}{ Potatoes } \\
\hline None & 1.00 (reference) & 1.00 (reference) \\
\hline$<122 \mathrm{~g}$ & $0.54(0.26-1.12)$ & $0.53(0.25-1.12)$ \\
\hline \multirow[t]{2}{*}{$\geq 122 \mathrm{~g}$} & $0.41(0.19-0.88)$ & $0.42(0.19-0.91)$ \\
\hline & $p=0.008$ & $p=0.012$ \\
\hline \multicolumn{3}{|l|}{ Legumes } \\
\hline None & 1.00 (reference) & 1.00 (reference) \\
\hline$<300 \mathrm{~g}$ & $0.71(0.28-1.80)$ & $0.73(0.28-1.88)$ \\
\hline \multirow[t]{2}{*}{$\geq 300 \mathrm{~g}$} & $0.44(0.20-1.02)$ & $0.39(0.16-0.97)$ \\
\hline & $p=0.042$ & $p=0.037$ \\
\hline \multicolumn{3}{|l|}{ Vegetables } \\
\hline None & 1.00 (reference) & 1.00 (reference) \\
\hline$<190 \mathrm{~g}$ & $0.71(0.37-1.35)$ & $0.69(0.36-1.35)$ \\
\hline \multirow[t]{2}{*}{$\geq 190 \mathrm{~g}$} & $0.41(0.21-0.81)$ & $0.39(0.19-0.78)$ \\
\hline & $p=0.006$ & $p=0.005$ \\
\hline \multicolumn{3}{|l|}{ Fruits } \\
\hline None & 1.00 (reference) & 1.00 (reference) \\
\hline$<261 \mathrm{~g}$ & $0.70(0.40-1.23)$ & $0.67(0.37-1.21)$ \\
\hline \multirow[t]{2}{*}{$\geq 261 \mathrm{~g}$} & $0.81(0.46-1.4 I)$ & $0.89(0.50-1.59)$ \\
\hline & $p=0.425$ & $p=0.645$ \\
\hline \multicolumn{3}{|c|}{ Fruits and/or vegetables } \\
\hline None & 1.00 (reference) & 1.00 (reference) \\
\hline$<360 \mathrm{~g}$ & $0.42(0.16-1.08)$ & $0.31(0.11-0.85)$ \\
\hline \multirow[t]{2}{*}{$\geq 360 \mathrm{~g}$} & $0.27(0.10-0.73)$ & $0.21(0.07-0.60)$ \\
\hline & $p<0.001$ & $p=0.009$ \\
\hline \multicolumn{3}{|l|}{ Meat } \\
\hline None & I.00 (reference) & 1.00 (reference) \\
\hline$<100 \mathrm{~g}$ & $1.30(0.73-2.33)$ & $1.46(0.80-2.65)$ \\
\hline \multirow[t]{2}{*}{$\geq 100 \mathrm{~g}$} & $2.52(1.43-4.44)$ & $2.51(1.35-4.65)$ \\
\hline & $p=0.002$ & $p=0.004$ \\
\hline Red meat & & \\
\hline None & I.00 (reference) & 1.00 (reference) \\
\hline$<90 \mathrm{~g}$ & $1.40(0.74-2.65)$ & $1.49(0.77-2.90)$ \\
\hline$\geq 90 \mathrm{~g}$ & 2.31 (1.32-4.05) & $2.31(1.28-4.19)$ \\
\hline & $p<0.001$ & $p=0.005$ \\
\hline Eggs & & \\
\hline None & 1.00 (reference) & 1.00 (reference) \\
\hline$<50 \mathrm{~g}$ & $1.09(0.47-2.56)$ & $1.16(0.49-2.78)$ \\
\hline$\geq 50 \mathrm{~g}$ & $0.45(0.17-1.19)$ & $0.50(0.19-1.33)$ \\
\hline & $p=0.153$ & $p=0.248$ \\
\hline Dairy prod & & \\
\hline None & I.00 (reference) & 1.00 (reference) \\
\hline$<130 \mathrm{~g}$ & I.62 (0.86-3.04) & $1.50(0.78-2.90)$ \\
\hline$\geq 130 \mathrm{~g}$ & $1.16(0.61-2.21)$ & $1.16(0.60-2.26)$ \\
\hline & $p=0.864$ & $p=0.840$ \\
\hline Fish-sea foc & & \\
\hline None & 1.00 (reference) & 1.00 (reference) \\
\hline$<85 \mathrm{~g}$ & $0.45(0.2 \mathrm{I}-0.96)$ & $0.46(0.2 \mathrm{I}-0.98)$ \\
\hline$\geq 85 \mathrm{~g}$ & $0.82(0.43-1.59)$ & $0.90(0.46-1.78)$ \\
\hline & $p=0.226$ & $p=0.363$ \\
\hline
\end{tabular}

\footnotetext{
I Logistic regression analysis including consumption of foods (none, below, or above median consumption) as independent variable. $P$ values for linear trends as presented.

${ }^{2}$ Logistic regression analysis including consumption of foods (none, below, or above median consumption), district of residence, body mass index, energy intake, consumption of tobacco, coffee, and alcohol as independent variables. $P$ values for linear trends as presented.
} 
founding) and limitation (as the sample is not representative of the general Greek adult population) of the survey.

Despite these limitations, there are several findings in this study that are worth to be discussed. In this sample of apparently healthy Cretan adults, sub-optimal folate levels were found in $6.8 \%$ of men and $2.1 \%$ of women, using serum concentrations $\leq 7 \mathrm{nmol} / \mathrm{l}$ as a cut-off value [16]. Depending on the criteria used, the proportion of subjects with impaired folate status in other studies ranges 0-79\% [18-21]. Differences in serum folate concentrations and cut-off values may be due to analytical methods, race-ethnicity differences and genetic backgrounds $[1,22]$. The mean daily intake of folate by the study subjects $(294 \mu \mathrm{g} /$ $\mathrm{d}$ in men, $247 \mu \mathrm{g} / \mathrm{d}$ in women) also stands between lower figures that have been reported by Plannells et al. [19] for Spanish adults (205 $\mu \mathrm{g} / \mathrm{d}$ in men, $197 \mu \mathrm{g} / \mathrm{d}$ in women) and higher ones that Ford et al. [21] and Rasmussen et al. [23] have described for US men $(343 \mu \mathrm{g} / \mathrm{d})$ and Dutch women $(283 \mu \mathrm{g} / \mathrm{d}$ in the $20-35$-year-old group $)$, respectively. In contrast to the low prevalence of sub-optimal folate concentrations, $>75 \%$ of the study participants did not meet the RDI for folate ( $400 \mu \mathrm{g} /$ day). Such a discrepancy between serum folate levels and dietary folate intake has been reported in several other surveys, including those where dietary folate intake was assessed by 3 -day dietary records or food-frequency questionnaires, and is explained by insufficient capturing of important sources of dietary folate by dietary records [20,23-25]. As already discussed, regular use of vitamin supplements was not recorded in our survey, which may have resulted in underestimation of dietary folate intake. Finally, some researchers argue that total homocysteine is a more sensitive indicator of folate status than is serum (or erythrocyte) concentration of the vitamin $[20,26]$. Similarly to the results of other studies $[19,20]$, men had higher mean intakes of dietary folate than women, but when expressed by energy intake, women had higher intake of folate than men. This might - at least in part - explain the higher serum folate concentrations in women, although other factors (e.g. hormonal, bioavailabilty of dietary folate etc.) may be responsible for this discrepancy.

In both men and women, subject age was positively related to serum folate levels. One possible explanation for this association is the higher intake of folate and folate-rich foods (especially fruits and vegetables) with increasing age among adults (data not shown). A similar trend has been reported in other studies and is generally attributed to the preference for more "healthy" or "traditional" diets among older adults $[19,20,27]$. With regard to the adult population in Crete, recent data indicate the gradual abandonment of the traditional Cretan diet in favour of more "westernised" diets, with consumption of higher amounts of saturated fat, meat, and cheese, and lower amounts of fruits, vegetables, legumes, and fibre [9$11]$.

In agreement with several other studies [28-32], serum folate was inversely related to total homocysteine concentrations. Hyperhomocysteinaemia is a well-established risk factor for atherothrombotic disease, Alzheimer's disease and other neuropsychiatric disorders, osteoporosis and hip fractures $[33,34]$. This overlap of medical disorders that are linked both to increased homocysteine and inadequate folate status has led to the suggestion that the disease-promoting effects of low folate are mediated through increased homocysteine levels $[1,4,7,32,35]$. Yet, recent data indicate that folate may act independently of homocysteine, especially through its direct effects on vascular endothelium and cellular redox status [1].

Another finding was the inverse relationship between tobacco consumption and serum folate concentrations. Smokers had significantly lower serum folate levels than non-smokers, and serum folate concentrations decreased by increasing consumption of cigarettes. A negative association between smoking and serum folate has been reported in other studies $[19,28,29,32,36]$, and is generally attributed to the different nutritional status of smokers. More specifically, smokers tend to consume lower amounts of several vitamins, fruits and vegetables, resulting in decreased intake of dietary folate [12,37-39]. Similarly, in our study, the association between smoking and serum folate abolished its statistical significance after controlling for intakes of dietary folate, vitamins and C. It should be noted, however, that smoking may have more direct anti-folate effects, producing local vitamin deficiency in individual tissues as demonstrated by Piyathilake et al. [40].

In the present study, serum folate concentrations were inversely related to coffee consumption. Such a relationship has only been shown indirectly, in studies examining serum total homocysteine levels in association with coffee intake. In some of these studies, the positive association between coffee consumption and homocysteine was lost after accounting for serum folate and/or dietary folate intake, indicating a negative association between coffee intake and folate status [29-32]. As in the case of tobacco consumption, the association between serum folate and coffee was confounded by differences in nutrient intakes.

The results from the dietary survey demonstrated significant associations between serum folate and intakes of several important nutrients, including MUFA, fibre, calcium, magnesium, folate, and vitamins $\mathrm{A}, \mathrm{E}, \mathrm{C}, \mathrm{B}_{1}$, and $\mathrm{B}_{6}$, independently of other confounders. A relationship between dietary folate intake and serum folate concentrations has 
been reported in some $[18,19,23]$ but not all [20] studies. The favourable associations between serum folate and dietary micronutrients were reflected by differences in consumption of various foods. Individuals with higher intakes of potatoes, legumes, fruits and/or vegetables - all these foods considered major sources of folate $[19,20]$ had significantly decreased risk for low serum folate (below the $1^{\text {st }}$ quartile), compared to those with no consumption. Conversely, higher intakes of cereals and meat products were related to decreased serum folate concentrations. These findings are in accordance with those reported by both cross-sectional [41-45] and diet-intervention studies $[46,47]$, which suggest a positive association between folate status and a dietary pattern characterized by high consumption of fruits, vegetables, legumes and low consumption of refined cereals and meat. It should be noted however, that the lower intakes of cereals and meat among the study subjects with lower serum folate levels might be simply due to substitution by other foods, namely fruits, vegetables, and legumes. Finally, an alternative explanation for the associations between serum folate levels and nutrients and foods, might be that serum folate serves as an overall nutritional biomarker and indicator of diet and health quality $[48,49]$.

\section{Conclusion}

Conclusively, in this cross-sectional study of healthy Cretan adults we found various demographic, lifestyle and dietary factors associated with serum folate concentrations. Considering the importance of folate in health maintenance and prevention of chronic disease, it is important to increase the public's awareness on modifiable lifestyle habits and especially diet, associated with improved folate status. In view of the high percentage of adults with inadequate intake of dietary folate, our results also emphasize the need to undertake large-scale epidemiological studies within the general Greek adult population, in order to assess the prevalence of impaired folate status, and further examine associations between dietary patterns, serum folate, and chronic disease risk.

\section{Competing interests}

The author(s) declare that they have no competing interests.

\section{Authors' contributions}

$\mathrm{CH}$ performed blood sampling, collected data, and reviewed the manuscript. GB collected data and drafted the manuscript. ML collected data and carried out the statistical analysis. In JS' laboratory biochemical measurement of serum folate, vitamin $B_{12}$ and homocysteine was performed. JS also reviewed the manuscript. AK conceived of the study, participated in its design, and helped to draft the manuscript. All authors read and approved the final manuscript.

\section{Acknowledgements}

We would like to acknowledge the assistance of Sofia Flouri in manuscript preparation. We also thank Joanna Moschandreas for commenting on the manuscript.

\section{References}

I. Stover P): Physiology of folate and vitamin $\mathrm{B} / 2$ in health and disease. Nutr Rev 2004, 62(6):S3-SI 2.

2. Molloy AM: Folate and homocysteine interrelationships including genetics of the relevant enzymes. Curr Op Lipidol 2004, I5:49-57.

3. Choi SW, Mason JB: Folate and carcinogenesis: an integrated scheme. J Nutr 2000, 130:129-132.

4. Moat SJ, Land D, McDowell IFW, Clarke ZL, Madhavan AK, Lewis MJ, Goodfellow J: Folate, homocysteine, endothelial function and cardiovascular disease. J Nutr Biochem 2004, 15:64-79.

5. Duthis SJ, Whalley LJ, Collins AR, Leaper S, Berger K, Deary IJ: Homocysteine, B vitamin status, and cognitive function in the elderly. Am J Clin Nutr 2002, 75:908-913.

6. Mattson MP, Kruman II, Duan W: Folic acid and homocysteine in age-related disease. Ageing $\operatorname{Res} \operatorname{Rev} 2002$, I:95- I I I.

7. Rampersaud GC, Kauwell GPA, Bailey LB: Folate: a key to optimizing health and reducing disease risk in the elderly. J Am Coll Nutr 2003, 22(I): I-8.

8. Kafatos AG, Kouroumalis I, Vlachonikolis J, Theodorou C, Labadarios $\mathrm{D}$ : Coronary-heart disease risk-factor status of the Cretan urban population in the 1980s. Am J Clin Nutr I991, 54:59I-598.

9. Kafatos AG, Diacatou A, Voukiklaris GE, Nikolakakis N, Vlachonikolis J, Kounali D, Mamalakis G, Dontas AS: Heart disease risk-factor status and dietary changes in the Cretan population over the past 30y: the Seven Countries Study. Am J Clin Nutr 1997, 65: $1882-1886$.

10. Voukiklaris GE, Kafatos AG, Dontas AS: Changing prevalence of coronary heart disease risk factors and cardiovascular diseases in men of a rural area of Crete from 1960 to 1991. Angiology 1996, 47:43-49.

II. Kafatos AG, Verhagen H, Moschandreas J, Apostolaki I, Van Westerop J: Mediterranean diet of Crete: foods and nutrient content. J Am Diet Assoc 2000, 100:1487-I493.

12. Bertsias G, Lindardakis M, Mammas I, Kafatos AG: Fruit and vegetables consumption in relation to health and diet of medical students in Crete, Greece. Int J Vitam Nutr Res 2005, 75(2): $107-117$.

13. O'Broin S, Kelleher B: Microbiological assay on microtitre plates of folate in serum and red cells. J Clin Path 1992, 45:344-347.

14. Kelleher B, O'Broin S: Microbiological assay for vitamin B /2 performed in 96-microtitre plate. J Clin Path 1991, 44:592-595.

15. Araki A, Sako Y: Determination of free and total homocysteine in human plasma by high performance liquid chromatography with fluorescence detection. J Chromatogr 1987, 422:43-52.

16. Clarke R, Grimley Evans J, Scheede J, Nexo E, Bates C, Fletcher A, Prentice A, Johnston C, Ueland P, Refsum H, Sherliker P, Birk J, Whitlock G, Breeze E, Scott J: Vitamin B 12 and folate deficiency in later life. Age Ageing 2004, 33:34-4I.

17. Fairfield KM, Fletcher RH: Vitamins for chronic disease prevention. J Am Med Assoc 2002, 287:3। I6-3I26.

18. Brussaard JH, Loewik MRH, van der Berg H, Brants HAM, Goldbohm RA: Folate intake and status among adults in the Netherlands. Eur J Clin Nutr 1997, 5 I:S46-S50.

19. Planells E, Sanchez C, Montellano MA, Mataix J, Llopis J: Vitamins B6 and $B I 2$ and folate status in an adult Mediterranean population. Eur J Clin Nutr 2003, 57:777-785.

20. Alfthan G, Laurinen MS, Valsta LM, Pastinen T, Aro A: Folate intake, plasma folate and homocysteine status in a random Finnish population. Eur J Clin Nutr 2003, 57:81-88.

21. Ford ES, Bowman BA: Serum and red blood cell folate concentrations, race, and education: findings from the third National Health and Nutrition Examination Survey. Am J Clin Nutr 1999, 69:476-48I. 
22. Perry CA, Renna SA, Khitun E, Ortiz M, Moriarty DJ, Caudill MA: Ethnicity and race influence the folate status response to controlled folate intakes in young women. J Nutr 2004, I 34: I 786- I792.

23. Rasmussen LB, Ovesen L, Bulow I, Knudsen N, Laurberg P, Perrild H: Folate intake, lifestyle factors, and homocysteine concentrations in younger and older women. Am J Clin Nutr 2000, 72: I 156-I 163.

24. Drogan D, Klipstein-Grobusch K, Wans S, Luley C, Boeing H, Dierkes $\mathrm{J}$ : Plasma folate as marker of folate status in epidemiological studies: the European Investigation into Cancer and Nutrition (EPIC)-Postdam study. Br J Nutr 2004, 92:489-496.

25. Wolters $M$, Hermann S, Hahn A: B vitamin status and concentrations of homocysteine and methylmalonic acid in elderly German women. Am J Clin Nutr 2003, 78:765-772.

26. Allen RH, Stabler SP, Savage DG, Lindenbaum J: Metabolic abnormalities in cobalamin (vitamin BI2) and folate deficiency. FASEB J 1993, 7: I 344- I353.

27. Scali J, Richard A, Gerber M: Diet profiles in a population sample from Mediterranean southern France. Public Health Nutr 200I, 4:173-182

28. Ganji V, Kafai MR: Demographic, health, lifestyle, and blood vitamin determinants of serum total homocysteine concentrations in the third National Health and Nutrition Examination Survey, I 988-1994. Am J Clin Nutr 2003, 77:826-833.

29. Jacques PF, Bostom AG, Wilson PWF, Rich S, Rosenberg IH, Selhub $\mathrm{J}$ : Determinants of plasma total homocysteine concentration in the Framingham Offspring cohort. Am J Clin Nutr 200I, 73:613-62I.

30. Mennen LI, Courcy GP, Guilland JC, Ducros V, Bertrais S, Nicolas JP, Maurel M, Zarebska M, Favier A, Franchisseur C, Hercberg S, Galan $P$ : Homocysteine, cardiovascular disease risk factors, and habitual diet in the French Supplementation with Antioxidant Vitamins and Minerals Study. Am J Clin Nutr 2002, 76: I279-I 289

31. Saw SM, Yuan JM, Ong CN, Arakawa K, Lee HP, Coetzee GA, Yu MC: Genetic, dietary, and other lifestyle determinants of plasma homocysteine concentrations in middle-aged and older Chinese men and women in Singapore. Am J Clin Nutr 2001, 73:232-239.

32. Ueland $\mathrm{P}$, Nygaord $\mathrm{O}$, Vollset SE, Refsum $\mathrm{H}$ : The Hordaland Homocysteine Studies. Lipids 200I, 36(Suppl):S33-S39.

33. Selhub J, Bagley LC, Miller J, Rosenberg IH: B vitamins, homocysteine, and neurocognitive function in the elderly. Am J Clin Nutr 2000, 71:6|4S-620S

34. Jacobsen DW: Homocysteine and vitamins in cardiovascular disease. Clin Chem 1998, 44:1833-1843.

35. Verhaar MC, Stroes E, Rabelink TJ: Folates and cardiovascular disease. Arterioscler Thromb Vasc Biol 2002, 22:6-13.

36. O'Callaghan P, Meledy E, Fitzgerald T, Graham I: Smoking and plasma homocysteine. Eur Heart J 2002, 23: I 580-I 586.

37. Subar AF, Harlan LC, Mattson ME: Food and nutrient intake differences between smokers and non-smokers in the USA. Am J Public Health 1990, 80: I323-I329.

38. Palaniappan U, Starkey LJ, O'Loughlin J, Gray-Donald K: Fruit and vegetable consumption is lower and saturated fat intake is higher among Canadians reporting smoking. J Nutr 200I, I31:1952-1958.

39. Marangon K, Herbeth B, Lecomte E, Paul-Dauphin A, Grolier P, Chancerelle $Y$, Artur $Y$, Siest G: Diet, antioxidant status, and smoking habits in French men. Am J Clin Nutr 1998, 67:23 I-239.

40. Piyathilake CJ, Hine RJ, Dasanayake AP: Effect of smoking on folate levels in buccal mucosal cells. Int J Cancer I992, 52:566-569.

4I. Tucker KL, Selhub J, Wilson PW, Rosenberg IH: Dietary intake pattern related to plasma folate and homocysteine concentrations in the Framingham Heart Study. J Nutr 1996, I 26( I 2):3025-303 I.

42. Kerver JM, Yang EJ, Bianchi L, Song WO: Dietary patterns associated with risk factors for cardiovascular disease in healthy US adults. Am J Clin Nutr 2003, 78: I I03-I I I0.

43. Fung TT, Rimm EB, Spiegelman D, Rifai N, Tofler GH, Willett WC, $\mathrm{Hu}$ FB: Association between dietary patterns and plasma biomarkers of obesity and cardiovascular disease risk. Am J Clin Nutr 2001, 73:6I-67.
44. Gao X, Yao M, McCrory MA, Ma G, Li Y, Roberts SB, Tucker KL: Dietary pattern is associated with homocysteine and $B$ vitamin status in an urban Chinese population. J Nutr 2003, I33:3636-3642.

45. Mann NJ, Li D, Sinclair AJ, Dudman NPB, Guo XW, Elsworth GR, Wilson AK, Kelly FD: The effect of diet on plasma homocysteine concentrations in healthy male subjects. Eur J Clin Nutr 1999, 53:895-899.

46. Brouwer IA, van Dusseldorp W, West CE, Meyboom S, Thomas CMG, Duran M, van het Hof KH, Eskes TKAB, Hautvast JGAJ, Steegers-Theunissen RPM: Dietary folate from vegetables and citrus fruit decreased plasma homocysteine concentrations in humans in a dietary controlled trial. J Nutr 1999, I 29: I I35-1 I39.

47. Kiefer I, Prock P, Lawrence C, Wise J, Bieger W, Bayer P, Rathmanner $T$, Kunze M, Rieder A: Supplementation with mixed fruit and vegetable juice concentrates increased serum antioxidants and folate in healthy adults. J Am Coll Nutr 2004, 23(3):205-2 I I.

48. Kant AK, Graubard BI: A comparison of three dietary pattern indexes for predicting biomarkers of diet and disease. J Am Coll Nutr 2005, 24(4):294-303.

49. Neuhouser ML, Patterson RE, King IB, Horner NK, Lampe JW: Selected nutritional biomarkers predict diet quality. Public Health Nutr 2003, 6(7):703-709.
Publish with Bio Med Central and every scientist can read your work free of charge

"BioMed Central will be the most significant development for disseminating the results of biomedical research in our lifetime. "

Sir Paul Nurse, Cancer Research UK

Your research papers will be:

- available free of charge to the entire biomedical community

- peer reviewed and published immediately upon acceptance

- cited in PubMed and archived on PubMed Central

- yours - you keep the copyright

Submit your manuscript here:

http://www.biomedcentral.com/info/publishing_adv.asp
BioMedcentral 